\title{
Oxidation states of the upper mantle recorded by megacryst ilmenite in kimberlite and type $A$ and $B$ spinel lherzolites
}

\author{
R.J. Arculus ${ }^{1, ~ *}$, J.B. Dawson ${ }^{2}$, R.H. Mitchell ${ }^{3}$, D.A. Gust ${ }^{1}$, and R.D. Holmes ${ }^{1}$ \\ ${ }^{1}$ Research School of Earth Sciences, Australian National University, P.O. Box 4, Canberra, A.C.T., 2600 Australia \\ ${ }^{2}$ Department of Geology, University of Sheffield, Sheffield S13JD, UK \\ ${ }^{3}$ Geology Department, Lakehead University, Thunder Bay, Ontario, Canada P7B 5E1
}

\begin{abstract}
The intrinsic oxygen fugacities of homogeneous, inclusion-free, megacryst ilmenites from the Frank Smith, Excelsior, Sekameng and Mukorob kimberlite pipes in southern Africa, and the alnöitic breccia in the Solomon Islands have been determined. Similar measurements have been made of the type A and B spinel peridotites from San Carlos in Arizona. The type A peridotites are characterised by oxygen fugacities close to the iron-wüstite buffer, similar to those of equivalent peridotite specimens from other continental and island arc environments. In strong contrast, the type B peridotites and all of the ilmenite megacrysts range between the oxygen fugacities defined by the nickelnickel oxide and fayalite-magnetite-quartz buffers. A close relationship between type $B$ peridotites, oxidized metasomatizing fluids in the upper mantle and oxidized, silicaundersaturated magma types is suggested. It is unlikely that a solid elemental carbon phase can be an equilibrium crystallization product of kimberlite magmas if the ilmenite megacrysts represent the redox state of kimberlite melts. The ultimate source of the oxidizing fluids and the development of such a wide dispersion ( $>4$ orders of magnitude) in oxygen fugacities of the upper mantle is not clear, but may involve recycled lithosphere, fluids from the lower mantle or result from the relatively rapid diffusion of $\mathrm{H}_{2}$, compared with other potential volatile species, in the mantle.
\end{abstract}

\section{Introduction}

The oxidation state of the upper mantle reflects the variety of processes that have occurred since mantle formation about 4.5 Gyr ago. For example, protocore-mantle equilibrium, meteorite bombardment, magma extraction and infiltration, metasomatic fluxing and lithosphere recycling may all have combined to impose distinctive intrinsic oxygen fugacity $\left(f \mathrm{O}_{2}\right)$ signatures on specific mantle materials.

Up until the application of direct measurement of intrinsic $\mathrm{fO}_{2}$ 's of upper mantle-derived materials, most petrologists and geochemists had assumed that the oxidation states of volcanic gas species and the $f \mathrm{O}_{2}$-T relationships of erupted lavas closely reflect the $f \mathrm{O}_{2}$ of their source regions in the mantle (Haggerty 1978; Ringwood 1979). Sato (1972) demonstrated that some volcanic and hypabyssal rock types

\footnotetext{
Offprint requests to: R.J. Arculus

* Present address: Department of Geological Sciences, University of Michigan, 1006 C.C. Little Building, Ann Arbor, Michigan 48109 , USA
}

are characterized by relatively low $f \mathrm{O}_{2}$ 's, close to the magnetite-wüstite (MW) and iron-wüstite (IW) synthetic buffer values. Furthermore, Arculus and Delano (1981) showed that spinels from peridotite and megacryst assemblages found associated with alkali basaltic/basanitic explosive activity are close to IW in $f \mathrm{O}_{2}-T$ space.

In order to account for the discrepancy $(\simeq 4$ orders of magnitude) between the oxidation states displayed by most erupted volcanics (close to the fayalite-magnetite-quartz (FMQ buffer), and the reduced states found in upper mantle-derived rock types, Sato (1978) suggested that $\mathrm{H}_{2}$-loss from the melts must have occurred en route from source to surface eruption. This general mechanism had previously been advocated by Osborn (e.g. 1969) as an explanation for the low-Fe or oxidized trend of calcalkaline volcanic suites compared with the high-Fe (comparatively reduced) trend of differentiation found in some tholeiitic suites.

Arculus and Delano (1981) accepted the hypothesis of $\mathrm{H}_{2}$-loss as a possible explanation for the strong divergence in intrinsic $f \mathrm{O}_{2}$ values of spinel peridotites and erupted lavas, but pointed out the obvious anomaly that very few volcanic rock types preserve intermediate oxidation states between FMQ and IW. Some scatter of oxidation states might be anticipated as a function of the degree to which $\mathrm{H}_{2}$-loss had progressed, perhaps as a further consequence of speed of ascent from the upper mantle to the surface and original dissolved $\mathrm{H}_{2} \mathrm{O}$ contents.

However, there are some observations that conflict with the hypothesis of $\mathrm{H}_{2}$-loss as a general process capable of accounting for the comparatively oxidized state of terrestrial volcanics. For example, the persistent association of carbonate with deep-seated kimberlitic and nephelinitic volcanism, and the oxidation states of upper mantle source regions calculated from the assumption of thermodynamic equilibrium between phenocryst phases in erupted melts and source mineralogies all point to intrinsic $f \mathrm{O}_{2}$ values close to FMQ (Mitchell 1973, 1975; Mo et al. 1982; cf. Carmichael and Nicholls 1967).

It is possible to calculate the $f \mathrm{O}_{2}$ of upper mantle peridotite assemblages with equilibria of the type $6 \mathrm{Fe}_{2} \mathrm{SiO}_{4}+\mathrm{O}_{2}=$ $3 \mathrm{Fe}_{2} \mathrm{Si}_{2} \mathrm{O}_{6}+2 \mathrm{Fe}_{3} \mathrm{O}_{4}$ (eg O'Neill et al. 1982). Depending on the solution model adopted for the spinel phase, values ranging from IW to FMQ have been determined for specific nodule assemblages ( $\mathrm{O}^{\prime} \mathrm{Neill}$ and Wall in prep.), with the $\mathrm{Fe}^{3+}$-poor peridotites from San Carlos (Frey and Prinz 1978) giving calculated values at the reduced end of this range. Intriguingly, calculated $f \mathrm{O}_{2}$ values do not coincide with intrinsic $\mathrm{fO}_{2}$ measurements for the same samples and 
Table 1. Analyses of megacryst ilmenites in kimberlites and the alnöitic breccia of Malaita

\begin{tabular}{lccccccrr}
\hline Sample & FS-6(8) & FS-7(8) & E-6(10) & E-8(11) & S3 $^{\text {b }}$ & S4 $^{\text {b }}$ & M $^{\text {b }}$ & Ma(20) $^{\text {b }}$ \\
\hline $\mathrm{TiO}_{2}$ & 52.65 & 49.92 & 52.45 & 47.76 & 42.02 & 49.17 & 53.83 & 49.91 \\
$\mathrm{Al}_{2} \mathrm{O}_{3}$ & 0.73 & 0.53 & 0.80 & 0.27 & - & - & - & 0.52 \\
$\mathrm{Cr}_{2} \mathrm{O}_{3}$ & 0.22 & 0.75 & 0.87 & 0.94 & - & - & 1.04 & - \\
$\mathrm{Fe}_{2} \mathrm{O}_{3}{ }^{\text {a }}$ & 8.73 & 11.71 & 8.53 & 14.61 & 20.73 & 10.38 & 3.74 & 8.91 \\
$\mathrm{FeO}$ & 25.34 & 27.18 & 24.81 & 28.36 & 29.36 & 28.70 & 28.08 & 34.75 \\
$\mathrm{MnO}$ & 0.24 & 0.28 & 0.24 & 0.27 & - & - & 0.26 & 0.23 \\
$\mathrm{MgO}$ & 12.14 & 9.76 & 12.31 & 8.04 & 4.61 & 8.55 & 11.26 & 5.54 \\
\hline
\end{tabular}

a $\mathrm{Fe}_{2} \mathrm{O}_{3}$ calculated from $\mathrm{ABO}_{3}$ stoichiometry and total $\mathrm{Fe}$

b Major elements determined by X-ray fluorescence. All other analyses by electron microporbe. Numbers in parentheses indicate No. of analyses used to calculate the average presented in the table

$\mathrm{FS}=$ Frank Smith, $\mathrm{E}=$ Excelsior, $\mathrm{S}=$ Sekameng, $\mathrm{M}=$ Mukorob, $\mathrm{Ma}=$ Malaita

at least for the type A peridotites, the electrochemical cells return more reduced values than are calculated with the spinel solution model of O'Neill and Navrotsky (1983).

The consistent reproduction of highly precise and accurate data (as compared with gas equilibrium, thermogravimetric and thermodynamic calculation) for the free energies of formation of well-studied oxides (e.g. NiO, $\mathrm{CoO}$ and $\mathrm{Fe}_{1-x} \mathrm{O}$ - see Ulmer et al. 1976, Holmes and Arculus 1982 and in prep.), does not lend support to the possibility that the solid electrolyte cells used in intrinsic $\mathrm{fO}_{2}$ measurements are systematically in error. In order to account for the more reduced $\mathrm{fO}_{2}$ values measured in peridotite assemblages than those calculated using standard thermodynamic data and solution modelling, it is proposed that limited non-stoichiometry (cation excess) is present in spinels in peridotites. This defect structure may have such a low density as to be undetectable with standard electron microscopy (J.M. Fitzgerald, pers. comm.). However, the reproducible upand-down temperature cycling displayed by peridotite and megacryst spinel phases (Arculus and Delano 1981) is unlike the behaviour predicted for cation excess spinel solutions by Aragón and McCallister (1982). Nevertheless, there seems to be no reason to discount the intrinsic $f \mathrm{O}_{2}$ measurements obtained with single or poly-phase peridotite assemblages using solid electrolyte cells.

In an endeavour to explore further the range of oxidation states extant in the upper mantle, we have determined intrinsic $f \mathrm{O}_{2}$ 's of spinel peridotite samples from Japan (Arculus and Gust 1981) and magnetite-bearing plutonic cumulates associated with strongly alkaline basaltic activity in eastern Australia (Arculus and Wass, in prep.). In this paper, we report the results obtained for intrinsic $\mathrm{fO}_{2}$ measurements on megacryst ilmenites found in kimberlite and alnöitic breccia pines, and type $A$ and $B$ spinel peridotites from San Carlos in Arizona. Type A peridotites have also been called "chrome diopside type" or type I peridotites, and type B are known also as "aluminous augite type" or type II peridotites (Wilshire and Shervais 1975).

\section{Experimental methods and sample description}

Oxygen-specific, $\mathrm{Y}_{2} \mathrm{O}_{3}$-stabilized $\mathrm{ZrO}_{2}$ solid electrolytes were employed in the measurements. The electrolytes are manufactured by Ceramic Oxide Fabricators of Eaglehawk, Victoria (Australia). The apparatus is essentially as described by Arculus and Delano (1981) with minor modifications. Pure argon (Commonwealth Industrial Gases Special
Grade) was allowed to fill the sample-containing cell, rather than the complex and time-consuming compatible $\mathrm{CO}-$ $\mathrm{CO}_{2}$ gas mix procedure described by Arculus and Delano (1981). Repeated checks and calibration with standard metal-metal oxide assemblages show no significant deviation from accepted $T-f \mathrm{O}_{2}$ values for these assemblages in the temperature range of $900-1,400^{\circ} \mathrm{C}$. Temperatures are reproducible to within $1-2^{\circ} \mathrm{C}$, and $\log _{10} f \mathrm{O}_{2}$ values to better than \pm 0.05 units.

Ilmenite samples were obtained from kimberlite pipes in southern Africa and the alnöitic breccia on Malaita, Solomon Islands (Nixon and Boyd 1979). Polished sections of megacrysts were examined and microprobed to test for homogeneity and freedom from inclusions of extraneous material. In some samples, coatings and veins of the kimberlite host (e.g. serpentine, calcite and perovskite) were found, and this type of material was handpicked to avoid inclusion in the ilmenite sample. Additional sample selection was performed in order to obtain a range of $\mathrm{Fe}_{2} \mathrm{O}_{3} /$ $\mathrm{FeO}$ ratios, and as wide a range of geikielite and hematite contents as possible.

The ilmenite fragments were then gently ground, in order to avoid oxidation, in an agate "spex" mill. An aliquot of the fine powder was subjected to acid treatment to check for the presence of carbonate, and none of the data reported here was collected on carbonate-bearing powders. Microprobe analyses of the selected ilmenite samples are presented in Table 1.

The peridotite samples were sectioned and checked closely for the presence of hydrous phases and glass. We endeavoured to exclude this type of material from the samples chosen for study, but a very minor amount may have been incorporated. The bulk peridotite was finely and slowly ground in an agate "spex" mill. Analyses of the constituent minerals are presented in Table 2 . It should be noted that the two samples representative of the type A peridotite suite consist of chrome-rich diopside vein in a peridotite host. The features to note of the mineral compositional data are the $\mathrm{Mg}-\mathrm{Cr}$-rich nature of the olivine-pyroxenespinel assemblage of type A samples compared with the $\mathrm{Fe}-\mathrm{Al}$-rich phases forming the type B peridotites (see also Frey and Prinz (1978) for more detailed descriptions).

\section{Results}

The data obtained for the type A peridotites from San Carlos are presented in Table 3 and displayed in Fig. 1. Note 
Table 2. Analyses of phases present in San Carlos Type A and B peridotites

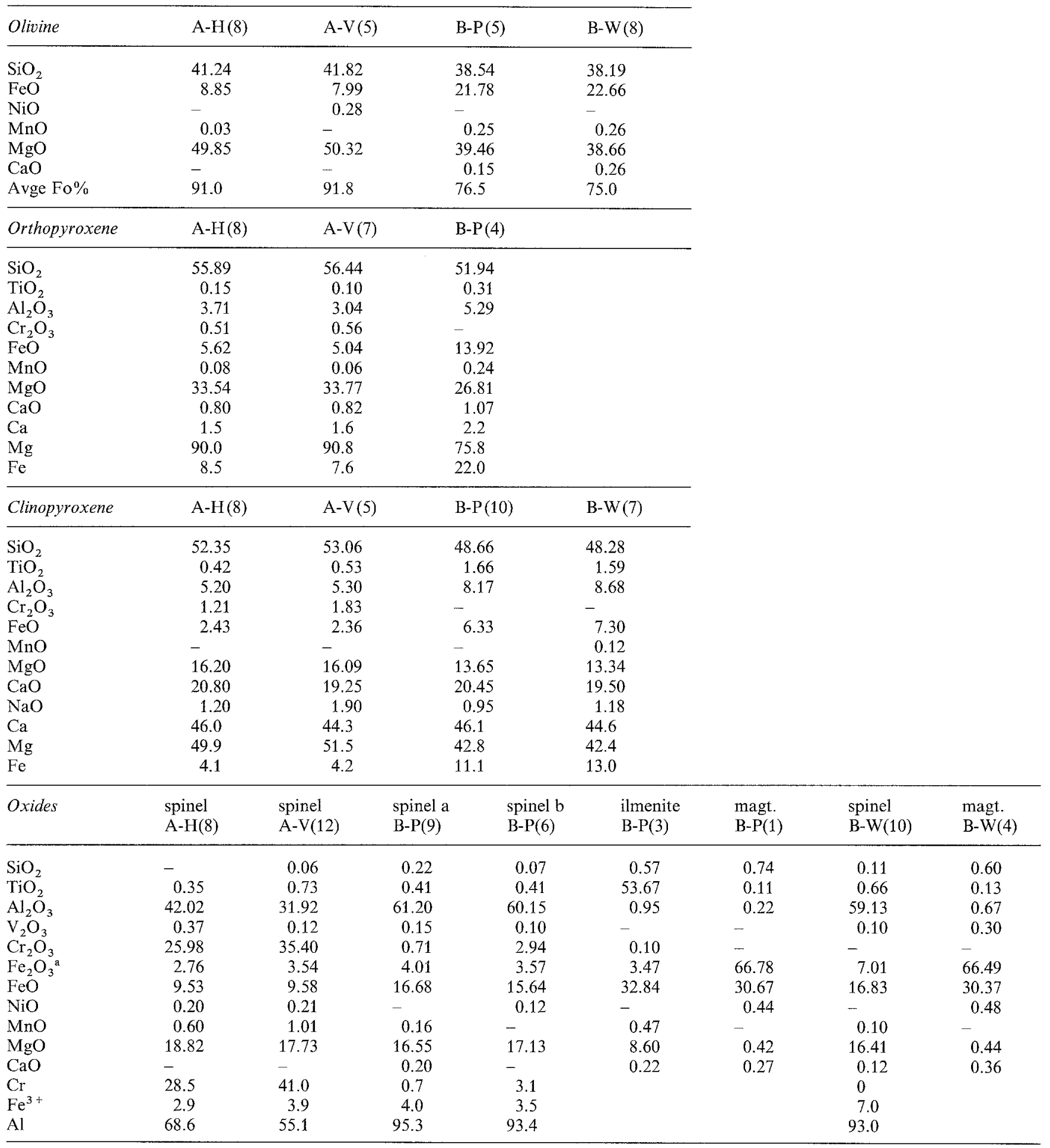

Abbreviations: $\mathrm{A}=\mathrm{A}$ type $\mathrm{B}=\mathrm{B}$ type; $\mathrm{H}=$ host $\mathrm{V}=\mathrm{Vein} ; \mathrm{P}=$ peridotite; $\mathrm{W}=$ wehrlite; magt. =magnetite. Numbers in parentheses are the number of point analyses used to calculate an average composition

In type B peridotite, there appear to be 2 generations of spinels given as " $a$ " and " $b$ ". In the type B wehrlite, pyrrhotite is present as small inclusions in clinopyroxene and spinel

$\mathrm{Fe}_{2} \mathrm{O}_{3}$ calculated from $\mathrm{AB}_{2} \mathrm{O}_{4}$ (spinel) and $\mathrm{ABO}_{3}$ (ilmenite) stoichiometry

that overall, the intrinsic $f \mathrm{O}_{2}$ values for these bulk peridotite samples are close to the IW buffer in $\mathrm{T}-f \mathrm{O}_{2}$ space, that consistent reversal up-and-down temperature were obtained and that an intersection of the best-fit lines drawn for the chrome diopside vein and its peridotite host is found close to $950^{\circ} \mathrm{C}$. This temperature is comparable with that defined by coexisting pyroxene compositions in type $\mathrm{A}$ peridotites at San Carlos (see Table 2 and Frey and Prinz 1978). Simi- 


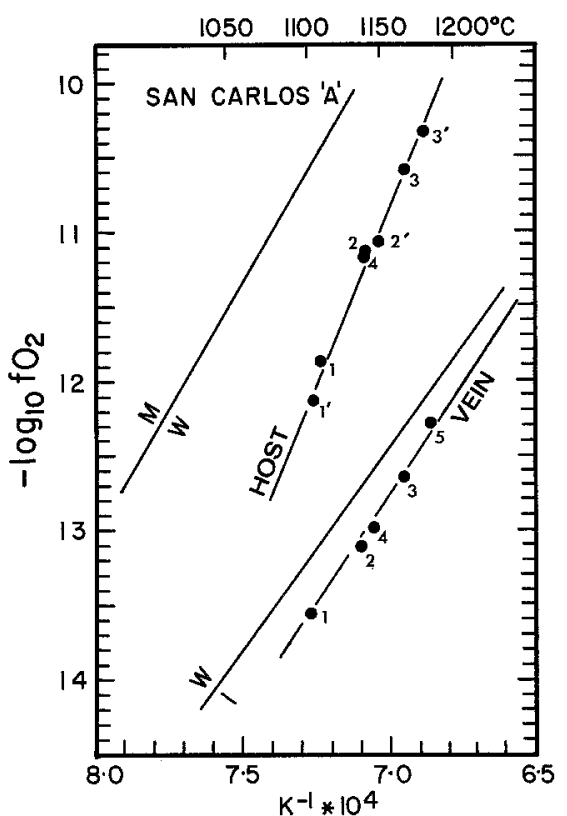

Fig. 1. $f \mathrm{O}_{2}$ vs. 1/T data for type A peridotite host and diopside-rich vein. Two different runs are included for the host and are indicated by the tick- and tick-free data points respectively. In this and following figures, the numbered points indicate the sequence of datum gathering at the specific temperatures

lar intrinsic $\mathrm{fO}_{2}$ values for type A San Carlos peridotites have been reported by Ulmer et al. (1980).

The intrinsic $f \mathrm{O}_{2}$ determinations at a variety of temperatures for the type $\mathrm{B}$ peridotites are presented in Table 4 and displayed in Fig. 2. Again, good reversals on temperature cycling were obtained. Note that the values of intrinsic $\mathrm{fO}_{2}$ for the type B samples are 4 orders of magnitude more

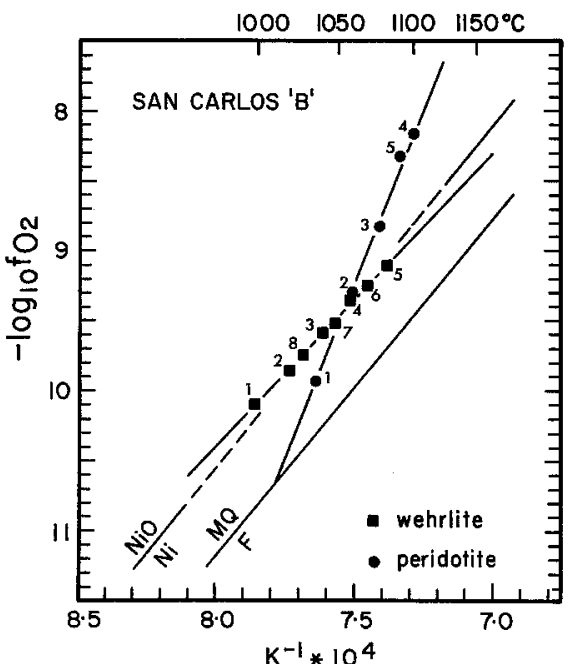

Fig. 2. $f \mathrm{O}_{2}$ vs. $1 / \mathrm{T}$ data for the type $\mathrm{B}$ peridotite and wehrlite

oxidized than the type A peridotites. At San Carlos, the type $B$ peridotites occur distributed throughout the basanitic host and are in close contact with type A inclusions.

Intrinsic $f \mathrm{O}_{2}$ data for the megacryst ilmenites are presented in Table 5 and displayed in the series of Figs. 3 to 6. Practically identical values were obtained whether on an up-or-down cycle of temperature. The data as a whole group in the vicinity of the FMQ and $\mathrm{Ni}-\mathrm{NiO}$ (NNO) buffers. For a given pair of samples from a single pipe, the ilmenite megacrysts show a consistently lower intrinsic $f \mathrm{O}_{2}$ with a decrease in $\mathrm{Fe}_{2} \mathrm{O}_{3} / \mathrm{FeO}$ ratio. But for the whole group of samples, such regularity is not so obvious (Fig. 7) and more subtle compositional and stoichiometric factors may be important.

Table 3. Intrinsic $f \mathrm{O}_{2}$ vs. T data for type A peridotites

\begin{tabular}{|c|c|c|c|c|c|c|c|}
\hline \multicolumn{4}{|l|}{ Host } & \multicolumn{4}{|l|}{ Vein } \\
\hline Point & $\mathrm{K}$ & $10^{4} / \mathrm{K}$ & $-\log _{10} f \mathrm{O}_{2}$ & Point & $\mathrm{K}$ & $10^{4} / \mathrm{K}$ & $-\log _{10} f \mathrm{O}_{2}$ \\
\hline 1 & 1,383 & 7.231 & 11.80 & 1 & 1,383 & 7.231 & 13.60 \\
\hline 2 & 1,413 & 7.077 & 11.12 & 2 & 1,412 & 7.082 & 13.06 \\
\hline 3 & 1,438 & 6.954 & 10.60 & 3 & 1,438 & 6.954 & 12.65 \\
\hline 4 & 1,412 & 7.082 & 11.15 & 4 & 1,418 & 7.052 & 12.90 \\
\hline $1^{\prime}$ & 1,377 & 7.262 & 12.07 & 5 & 1,458 & 6.859 & 12.33 \\
\hline $2^{\prime}$ & 1,423 & 7.027 & 11.05 & & & & \\
\hline $3^{\prime}$ & 1,453 & 6.882 & 10.33 & & & & \\
\hline
\end{tabular}

Table 4. Intrinsic $f \mathrm{O}_{2}$ vs. $\mathrm{T}$ data for type $\mathrm{B}$ peridotites

\begin{tabular}{|c|c|c|c|c|c|c|c|}
\hline \multicolumn{4}{|c|}{ Peridotite } & \multicolumn{4}{|c|}{ Wehrlite } \\
\hline Point & $\mathrm{K}$ & $10^{4} / \mathrm{K}$ & $-\log _{10} f \mathrm{O}_{2}$ & Point & $\mathrm{K}$ & $10^{4} / \mathrm{K}$ & $-\log _{10} f \mathrm{O}_{2}$ \\
\hline 1 & 1,309 & 7.639 & 9.90 & 1 & 1,273 & 7.855 & 10.10 \\
\hline 2 & 1,331 & 7.513 & 9.29 & 2 & 1,293 & 7.734 & 9.84 \\
\hline 3 & $1,350.5$ & 7.405 & 8.83 & 3 & 1,313 & 7.616 & 9.60 \\
\hline 4 & 1,374 & 7.278 & 8.13 & 4 & 1,333 & 7.502 & 9.34 \\
\hline \multirow[t]{4}{*}{5} & 1,363 & 7.336 & 8.31 & 5 & 1,353 & 7.391 & 9.10 \\
\hline & & & & 6 & 1,343 & 7.446 & 9.26 \\
\hline & & & & 7 & 1,321 & 7.570 & 9.63 \\
\hline & & & & 8 & $1,300.5$ & 7.689 & 9.71 \\
\hline
\end{tabular}


Table 5. Intrinsic $f \mathrm{O}_{2}$ vs. T data for megacryst ilmenites

\begin{tabular}{|c|c|c|c|c|c|c|c|}
\hline \multicolumn{4}{|l|}{$\mathrm{FS}-6$} & \multicolumn{4}{|l|}{ FS-7 } \\
\hline Point & $\mathrm{K}$ & $10^{4} / \mathrm{K}$ & $-\log _{10} f \mathrm{O}_{2}$ & Point & $\mathrm{K}$ & $10^{4} / \mathrm{K}$ & $-\log _{10} f \mathrm{O}_{2}$ \\
\hline 1 & 1,278 & 7.825 & 10.16 & 1 & 1,338 & 7.474 & 9.15 \\
\hline 2 & $1,309.5$ & 7.637 & 9.64 & 2 & 1,363 & 7.337 & 8.81 \\
\hline 3 & 1,333 & 7.502 & 9.27 & 3 & 1,383 & 7.231 & 8.62 \\
\hline 4 & 1,365 & 7.326 & 8.86 & 4 & 1,403 & 7.128 & 8.41 \\
\hline 5 & 1,288 & 7.764 & 9.92 & 5 & 1,423 & 7.027 & 8.19 \\
\hline \multirow[t]{4}{*}{6} & 1,245 & 8.032 & 10.32 & 6 & 1,373 & 7.283 & 8.70 \\
\hline & & & & 7 & $1,331.5$ & 7.510 & 9.26 \\
\hline & & & & 8 & 1,288 & 7.764 & 9.73 \\
\hline & & & & 9 & 1,255 & 7.968 & 10.14 \\
\hline \multicolumn{4}{|l|}{ E-6 } & \multicolumn{4}{|l|}{ E-8 } \\
\hline Point & $\mathrm{K}$ & $10^{4} / \mathrm{K}$ & $-\log _{10} f \mathrm{O}_{2}$ & Point & $\mathrm{K}$ & $10^{4} / \mathrm{K}$ & $-\log _{10} f \mathrm{O}_{2}$ \\
\hline 1 & 1,293 & 7.734 & 10.56 & 1 & $1,324.5$ & 7.550 & 9.15 \\
\hline 2 & 1,325 & 7.547 & 10.24 & 2 & 1,349 & 7.413 & 8.80 \\
\hline 3 & 1,360 & 7.353 & 9.73 & 3 & 1,371 & 7.294 & 8.55 \\
\hline 4 & 1,303 & 7.675 & 10.41 & 4 & 1,403 & 7.128 & 8.13 \\
\hline 5 & 1,345 & 7.435 & 9.90 & 5 & 1,423 & 7.027 & 7.93 \\
\hline 6 & 1,379 & 7.252 & 9.46 & & & & \\
\hline 7 & 1,402 & 7.133 & 9.20 & & & & \\
\hline 8 & 1,423 & 7.027 & 8.97 & & & & \\
\hline \multicolumn{4}{|l|}{ S3 } & \multicolumn{4}{|l|}{ S4 } \\
\hline Point & $\mathrm{K}$ & $10^{4} / \mathrm{K}$ & $-\log _{10} f \mathrm{O}_{2}$ & Point & $\mathrm{K}$ & $10^{4} / \mathrm{K}$ & $-\log _{10} f \mathrm{O}_{2}$ \\
\hline 1 & $1,320.5$ & 7.573 & 9.02 & 1 & 1,338 & 7.474 & 10.10 \\
\hline 2 & 1,344 & 7.440 & 8.73 & 2 & 1,358 & 7.364 & 9.84 \\
\hline 3 & 1,373 & 7.283 & 8.40 & 3 & 1,386 & 7.215 & 9.38 \\
\hline 4 & 1,264 & 7.911 & 10.09 & 4 & 1,407 & 7.107 & 9.08 \\
\hline 5 & 1,293 & 7.734 & 9.50 & 5 & 1,416 & 7.062 & 8.96 \\
\hline 6 & 1,324 & 7.553 & 9.05 & 6 & 1,394 & 7.174 & 9.30 \\
\hline 7 & 1,367 & 7.315 & 8.60 & 7 & $1,375.5$ & 7.270 & 9.50 \\
\hline 8 & 1,398 & 7.153 & 8.26 & & & & \\
\hline 9 & 1,412 & 7.082 & 8.04 & & & & \\
\hline 10 & 1,383 & 7.231 & 8.41 & & & & \\
\hline 11 & 1,363 & 7.337 & 8.65 & & & & \\
\hline \multicolumn{4}{|l|}{ M8 } & \multicolumn{4}{|c|}{ Malaita } \\
\hline Point & $\mathrm{K}$ & $10^{4} / \mathrm{K}$ & $-\log _{10} f \mathrm{O}_{2}$ & Point & $\mathrm{K}$ & $10^{4} / \mathrm{K}$ & $-\log _{10} f \mathrm{O}_{2}$ \\
\hline 1 & 1,263 & 7.918 & 10.58 & 1 & 1,283 & 7.794 & 9.47 \\
\hline 2 & 1,286 & 7.776 & 10.40 & 2 & 1,338 & 7.474 & 8.96 \\
\hline 3 & 1,309 & 7.639 & 10.12 & 3 & 1,393 & 7.179 & 8.46 \\
\hline 4 & 1,329 & 7.524 & 9.98 & 4 & 1,423 & 7.027 & 8.18 \\
\hline 5 & $1,347.5$ & 7.421 & 9.72 & 5 & 1,403 & 7.128 & 8.37 \\
\hline 6 & 1,379 & 7.252 & 9.41 & 6 & 1,443 & 6.930 & 7.99 \\
\hline 7 & 1,403 & 7.127 & 9.15 & 7 & 1,363 & 7.337 & 8.85 \\
\hline 8 & 1,373 & 7.283 & 9.48 & 8 & 1,364 & 7.331 & 8.84 \\
\hline 9 & 1,332 & 7.508 & 9.80 & 9 & 1,443 & 6.930 & 8.11 \\
\hline 10 & 1,290 & 7.752 & 10.28 & 10 & 1,278 & 7.825 & 9.89 \\
\hline \multirow[t]{2}{*}{11} & 1,314 & 7.610 & 10.02 & 11 & 1,279 & 7.819 & 9.69 \\
\hline & & & & 12 & 1,312 & 7.622 & 9.40 \\
\hline
\end{tabular}

In none of the experimental determinations of intrinsic $\mathrm{fO}_{2}$ has an "autoreduction" of the type described by Sato (1976) and Sato and Valenza (1980) been observed. Sato has shown that at temperatures in excess of $1,120^{\circ} \mathrm{C}$, a number of different igneous samples ranging from lunar volcanic glasses to mineral separates from horizons of the
Skaergaard layered intrusion display an irreversible drop in intrinsic $\mathrm{fO}_{2}$. Autoreduction has been attributed by Sato (e.g. 1979) to the presence of finely disseminated carbon in the samples. Carbon is unstable at 1 bar but undergoes oxidation (and hence reduction of the sample) only at high temperatures due to kinetic effects. Despite maintaining the 


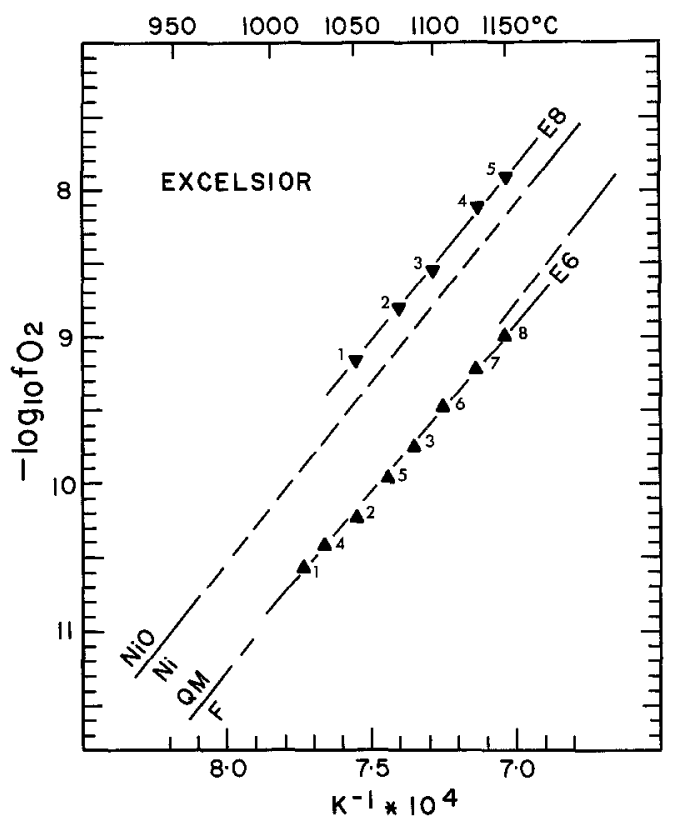

Fig. 3. $f \mathrm{O}_{2}$ vs. $1 / \mathrm{T}$ data for ilmenite megacrysts $\mathrm{E}-8$ and $\mathrm{E}-6$ from the Excelsior kimberlite pipe

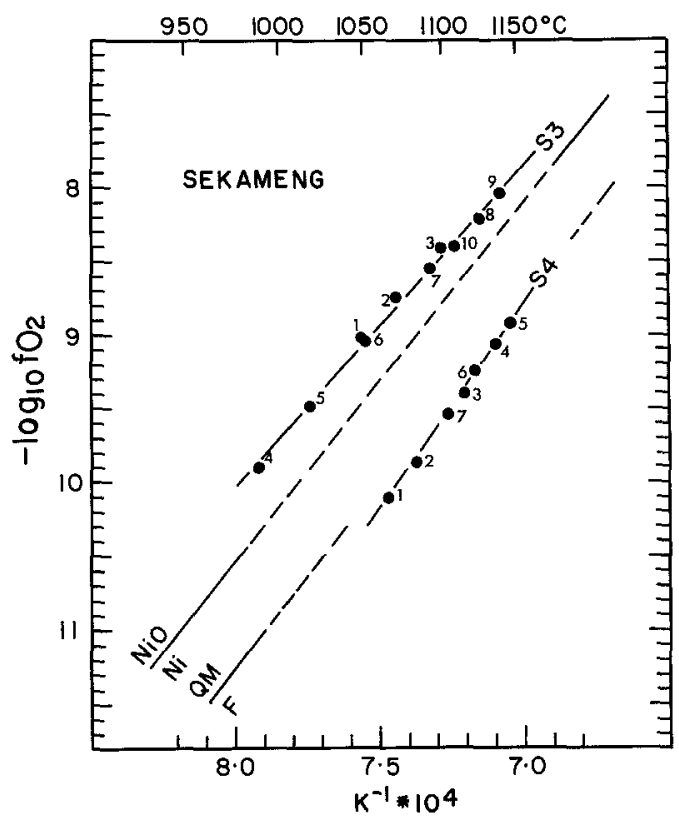

Fig. 4. $f \mathrm{O}_{2}$ vs. $1 / \mathrm{T}$ data for ilmenite megacrysts $\mathrm{S}-3$ and $\mathrm{S}-4$ from the Sekameng kimberlite pipe

San Carlos peridotite samples at temperatures of the order of $1,175^{\circ} \mathrm{C}$ for several days, no change in intrinsic $f \mathrm{O}_{2}$ took place. Furthermore, although held at somewhat lower temperatures but still in excess of $1,120^{\circ} \mathrm{C}$ and for many hours, none of the ilmenite megacrysts displayed any autoreduction.

We have also studied the intrinsic $f \mathrm{O}_{2}$ of the bulk peridotite host of one of the spinels studied by Arculus and Delano (1981). In the early part of an experimental run at a specific temperature, $f \mathrm{O}_{2}$ values coincident with IW were observed but at variable time intervals from minutes to several hours for different charges, an irreversible and progressive oxidation signal was recorded. Examination of

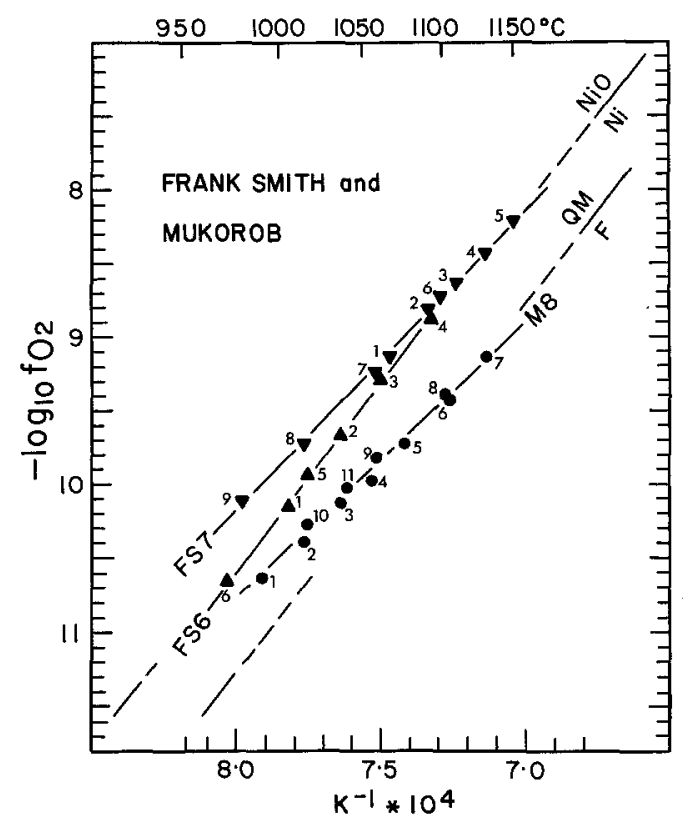

Fig. 5. $f \mathrm{O}_{2}$ vs. 1/T data for ilmenite megacrysts FS-7, FS-6 from the Frank Smith pipe, and M-8 from the Mukorob kimberlite pipe

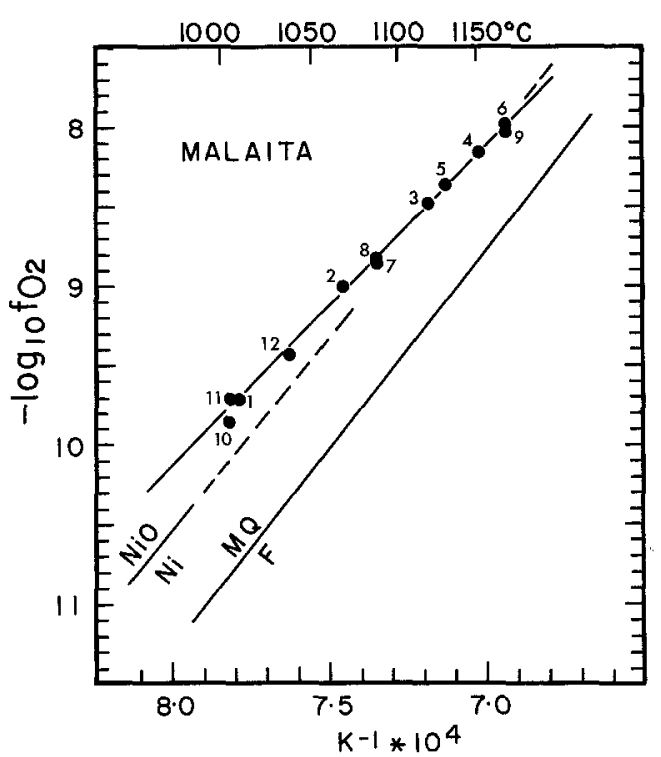

Fig. 6. $f \mathrm{O}_{2}$ vs. $1 / \mathrm{T}$ data for an ilmenite megacryst from the alnöitic breccia pipe on Malaita, Solomon Islands

the charges post-run reveals an oxidised (reddened) zone at the top of the sample, and a zone of dark discolouration of the thermocouple sheath/support ceramic in the region clear of the hot spot of the furnace. These results can be interpreted as resulting from the release of $\mathrm{CO}_{2}$ from the bulk peridotite during heating, reduction of $\mathrm{CO}_{2}$ and deposition of graphite in the cooler part of the electrolyte tube assembly, and consequent oxidation of the peridotite charge.

Our experience with amphibole-bearing peridotites from Ichinomegata (Japan) has suggested one possible explanation for the difference in behaviour observed between autoreductive and nonautoreductive samples. The presence of 
amphibole in the Ichinomegata peridotites correlated with the "autooxidation" of the sample (see Arculus and Gust 1981). In other words, a shift to higher intrinsic $f \mathrm{O}_{2}$ values at a specific temperature was observed as the experimental run progressed. This feature was not observed in amphibole-free peridotites. It is possible that at the temperatures of the experiment $\left(>1,000^{\circ} \mathrm{C}\right)$, dehydration of amphibole took place and $\mathrm{H}_{2}$ was then lost from the sample-bearing cell by breakdown of the evolved $\mathrm{H}_{2} \mathrm{O}$ and diffusion of $\mathrm{H}_{2}$ through the $\mathrm{ZrO}_{2}-\mathrm{Al}_{2} \mathrm{O}_{3}$ tube configuration that forms the cell.

In the case of the experimental configuration of Sato (e.g. 1972;1979), $\mathrm{H}_{2}-\mathrm{CO}_{2}$ gas mixtures are used to control the furnace atmosphere whereas in all of the experiments we have performed so far, $\mathrm{CO}-\mathrm{CO}_{2}$ gas mixtures are used. It seems to us that autoreduction may result from the diffusion of $\mathrm{H}_{2}$ into the sample-bearing cell in the same way that $\mathrm{H}_{2}$ apparently diffused out of our cells during the experiments with some Ichinomegata peridotites. However, it should be noted that a test for this possibility using different buffering gas mixtures during a study of Bushveld samples showed no variation in recorded signal (Elliott et al. 1982). But in the case of these Bushveld samples, no autoreduction was observed either, so the general problem remains unresolved. We are not attempting to ignore the undoubted presence of carbon-bearing species in the samples described here, but find no reason to question the validity of the results given the absence of any complex autoreduction (or autooxidation) effects.

\section{Discussion}

The first and most important observation to make of the results is the striking contrast in intrinsic $f \mathrm{O}_{2}$ 's now recorded for samples of different facies of upper mantle peridotite, and relict from high-pressure petrogenetic events (Fig. 8). In some respects it is reassuring that such a dispersion of oxidation states, not entirely unexpected, has been recorded. The intrinsic $f \mathrm{O}_{2}$ values, especially those in the vicinity of IW, seem credible rather than the result of some persistently anomalous equipment performance.

There remains of course the question of whether the intrinsic $f \mathrm{O}_{2}$ measurements recorded at 1 bar fairly reflect the values that exist in situ at upper mantle pressures. Providing the intrinsic $f \mathrm{O}_{2}$ is controlled in a given sample by solid state reactions rather than a function of volatile or fluid species control, then the relative-position in $\mathrm{T}-f \mathrm{O}_{2}$ space of the various peridotite and megacryst types with respect to standard buffer assemblages may be expected to remain unchanged (Sato 1972). This hypothesis has not been tested under a range of pressure conditions, but it is reasonable to assume that it is the case.

It is worth emphasising that the reduced intrinsic $f \mathrm{O}_{2}$ values around IW now recorded for type A peridotites from a variety of continental and even island arc environments, do not lend support to any hypothesis relating these peridotites directly as source material or restite to commonly erupted surface lavas. The process of $\mathrm{H}_{2}$-loss may account for some shift in oxidation states of erupted melts, but it is of interest to explore the possibility that strongly silicaundersaturated volcanic rock suites are not related to type A peridotites alone. Note however, that the intrinsic $\mathrm{fO}_{2}$ values recorded by Sato (1972) for olivine within a submarine-quenched Hawaiian tholeiite, relatively reduced intrin-

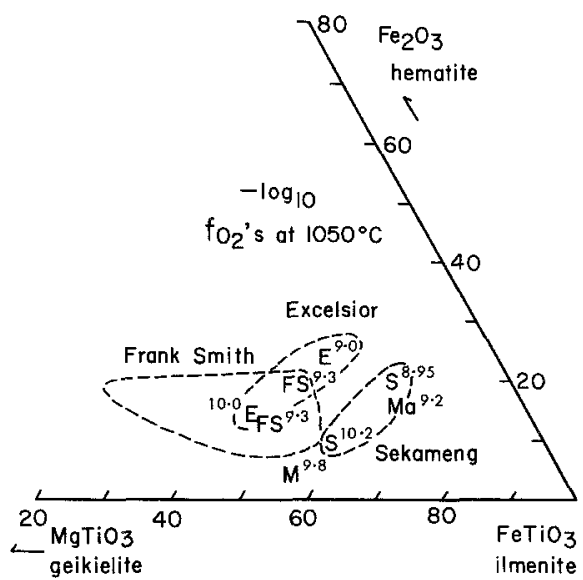

Fig. 7. Molar projection for the compositional range of ilmenite megacrysts studied in terms of hematite-ilmenite-geikielite components. Intrinsic $f \mathrm{O}_{2}$ data at $1,050^{\circ} \mathrm{C}(1,323 \mathrm{~K})$ are shown beside specific sample compositions

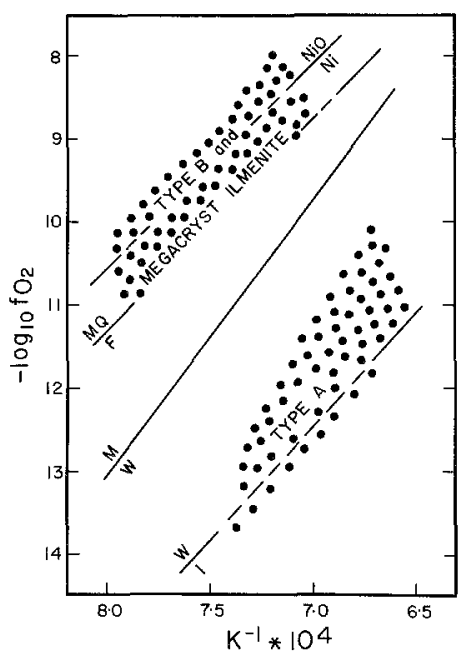

Fig. 8. Schematic representation of intrinsic $f \mathrm{O}_{2}$ vs. $1 / \mathrm{T}$ data for all peridotite and megacryst samples reported in this paper. In this figure, the dots represent the area in which individual plots fall, rather than specific experimental data points

$\operatorname{sic} f \mathrm{O}_{2}$ values (MW to IW) reported for major layered intrusions (Flynn et al. 1978; Sato and Valenza 1981; Arculus, unpublished data on the Bushveld), and the presence of reduced gas species in Galapagos Rift basalts (Muenow et al. 1982) may indicate major involvement of type A peridotite sources in some melt generation events.

A long-standing petrologic controversy surrounds the adequacy of models invoking a single peridotite source composition as a parental material for the spectrum of basalt types (from strongly alkaline to tholeiitic) found at a specific locality such as Hawaii, or from place to place on the Earth's surface. There have been a number of papers published relating the complex metasomatic events preserved in some peridotite fragments to the chemical and isotopic characteristics of alkalic basalt types (e.g. Boettcher and O'Neil 1980; Menzies and Murthy 1980; Lawless et al. 1979). One view of these metasomatized peridotites is that they contain either the precursor melts associated with alkalic basalt generation, or that volumes of metasomatized peridotites represent the source materials themselves - a 
distinction which relates to the time gap between metasomatism and basalt generation. The significant point is that non-metasomatized peridotite is regarded as insufficiently enriched in magmaphile elements to act as a source for alkali basalt types. A complex variety of metasomatized or "incompatible element" enriched (light rare earths, $\mathrm{Ba}, \mathrm{Sr}, \mathrm{P}, \mathrm{Nb}$, Ta are examples) peridotites are known, ranging from the mica-amphibole-rutile-ilmenite-diopside (MARID) nodule suite (Dawson and Smith 1977) through the type B peridotites of the sort described in this paper, to samples classified as type A peridotites but known to contain minor traces of phlogopite or amphibole (e.g. Frey et al. 1978; Frey and Prinz 1978).

The fact that type $\mathrm{B}$ peridotites are characterized by intrinsic $f \mathrm{O}_{2}$ 's in the vicinity of the NNO-FMQ buffers lends support to the grouping of metasomatic activity in the upper mantle with the comparably oxidized nature of alkalic basalt suites. For those nodule-bearing basalts in particular that appear to have ascended rapidly from upper mantle depths, it seems unnecessary to invoke oxidation en route to the surface via a process such as $\mathrm{H}_{2}$-loss. Rather, the source peridotite may have been oxidized during the melting event (influx of oxidized fluids) or by much earlier metasomatic processes. Melting of partially veined (type B in A) upper mantle can be expected to result in the dominance of type B peridotite facies in control of the oxidation state of the derivative melts. The origin of these oxidized portions of the upper mantle then becomes a key problem inextricably linked with the origin of metasomatizing fluids. Before pursuing this line of reasoning further, it is of interest to explore the implications of the intrinsic $f \mathrm{O}_{2}$ data obtained for the megacryst ilmenite samples.

The concensus of petrologic opinion concerning the origins of megacryst ilmenites in kimberlite is that they represent high-pressure cumulates related either to the host kimberlite itself, or at the least to some proto-kimberlitic magma (see Dawson 1980, for a review). The intrinsic $\mathrm{fO}_{2}$ values recorded for these ilmenite megacrysts may therefore be regarded as indications of the redox state prevailing in the source regions of the kimberlitic magmas.

Given the types of mineral assemblage characteristically found in kimberlites, it is possible to calculate the $f \mathrm{O}_{2}$ that must have prevailed during part of the crystallization history of the rock (e.g. Carmichael and Nicholls 1967; Mitchell 1975). There is always the possibility that the combination of uncertainties in thermodynamic data, solid solution models and the non-equilibrium of the phases employed in the calculation conspires to produce erroneous results. However, it is of interest that the $\mathrm{OO}_{2}$ of equilibration calculated by approaches such as those of Mitchell corresponds fairly closely to the intrinsic $\mathrm{fO}_{2}$ results reported here for the megacryst ilmenites. This fact lends credence to the hypothesis that for the most part, $\mathrm{Fe}^{2+} \rightleftarrows \mathrm{Fe}^{3+}$ exchange reactions buffer the oxidation state of the mantle and derivative melts, rather than carbon (either graphite or diamond) carbonate redox reactions. It is interesting that the intrinsic $\mathrm{fO}_{2}$ values for the ilmenite megacrysts are more oxidized than the values calculated by Eggler (1982) from the equilibrium $\mathrm{Fe}_{2} \mathrm{O}_{3}+2 \mathrm{FeSiO}_{3}=2 \mathrm{Fe}_{2} \mathrm{SiO}_{4}+1 / 2 \mathrm{O}_{2}$, and applied to assemblages of olivine-orthopyroxene-ilmenite in kimberlite. Reasons for the discrepancy are not clear at this stage.

The phenocryst versus xenocryst status of diamond in kimberlite has been discussed numerous times in the literature (e.g. Rosenhauer et al. 1977; Dawson 1980). Providing

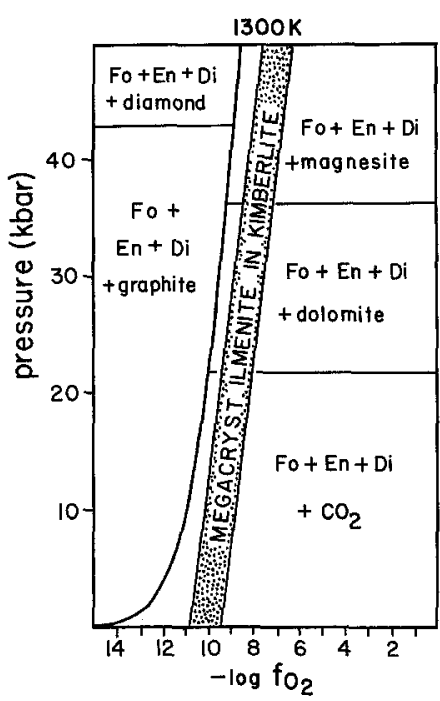

Fig. 9. Stability fields of carbonate-carbon species in peridotite mantle as a function of pressure and $f \mathrm{O}_{2}$ at a specific temperature, after Ryabchikov et al. (1981). The upper stability limit of elemental carbon would be at slightly more reduced $f \mathrm{O}_{2}$ values at pressures greater than $20 \mathrm{kbar}$ according to an analysis by Rosenhauer and Woermann (pers comm 1983). Superimposed on these fields is the $\mathrm{fO}_{2}$ range of ilmenite megacrysts in kimberlite

the ilmenite megacrysts faithfully record the oxidation states prevailing in the upper mantle source regions of this magma type, then it is possible to make some assessment of the extent to which diamond is an accidental inclusion in the host rock in which it is typically found.

The stability fields of carbon dioxide, carbonate, graphite and diamond in peridotite facies have been presented by Ryabchikov et al. (1981). In Fig. 9, the range of intrinsic $\mathrm{fO}_{2}$ 's of the megacryst ilmenites is superimposed on one of the isothermal, pressure versus $f \mathrm{O}_{2}$ plots of Ryabchikov et al. Providing the pressure versus $\mathrm{fO}_{2}$ dependency of the megacrysts is equivalent to the behaviour of a solid buffer assemblage such as FMQ, the extrapolation displayed in Fig. 9 should be valid. Variations in temperature make little qualitative difference in the pressure range of interest. The major features of the plot is that throughout the high pressure range traversed by kimberlite magmas, a carbonate phase is stable rather than graphite or diamond. It is possible that the relatively small difference in $f \mathrm{O}_{2}$ between the upper stability limit of diamond and the lower limit found in ilmenite megacrysts may be reduced by further studies. But it is apparent that the megacrysts as a group now define an $\mathrm{fO}_{2}$ range that is well above the stability field of a solid carbon phase.

The immediate conclusion to be drawn is that both graphite and diamond are xenocrysts in kimberlite. A corollorary is that any magma type, generated at appropriate depths and travelling speedily to the surface, should be capable of transporting diamond. In the case of kimberlite genesis, we are faced with the same problem of accounting for the existence of strongly oxidized source regions of the upper mantle as was described for the type A-B peridotite association, and the oxidized nature of many alkalic-basalt types. It would seem that substantial portions of the upper mantle, if representatively sampled by type A peridotites, are close to the IW buffer in terms of oxidation state. Under these redox conditions, graphite and diamond are stable 


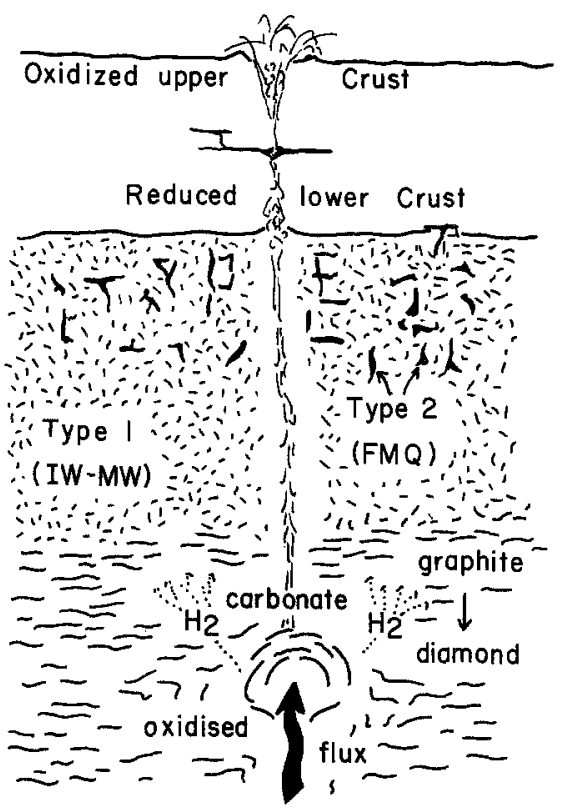

Fig. 10. Schematic representation of possible zones of contrasted $\mathrm{fO}_{2}$ in the upper mantle. As a consequence of the rapid diffusion of $\mathrm{H}_{2}$ away from a rising flux of volatile-rich magma, portions of the upper mantle are reduced while other zones become infiltrated by oxidized magma

phases. It is of great interest to determine the ultimate source of the oxidized fluids identified in the genesis of kimberlites and in formation of type B peridotite associations.

Some involvement of the upper layers of an oxidised (through exposure to the hydrosphere), recycled lithosphere is one possible explanation for the sources of these fluids (Arculus and Delano 1981). However, the isotopic signatures of kimberlites and metasomatized peridotites, whether they be the high $\mathrm{Rb} / \mathrm{Sr}-\mathrm{Nd} / \mathrm{Sm}$ sources of west Australian lamproites (Jaques et al. 1982), or the apparently chondritic fluids of Basu and Tatsumoto (1980, 1982), or even the relatively depleted sources of Menzies and Murthy (1980) do not seem to be straight forwardly recognisable as being derived from old, hydrated and oxidized lithosphere.

An alternative possibility is that the fluids represent long-term leakage of volatile-enriched components from zones of the lower mantle that are relict from disproportionation reactions of Fe-bearing silicates and oxides. Mao (1974) has demonstrated that reactions of the sort $3 \mathrm{Fe}^{2+} \rightleftarrows$ $2 \mathrm{Fe}^{3+}+\mathrm{Fe}^{0}$ may have been important in the formation of the Earth's core. It might be anticipated that fluid species in equilibrium with the phases remaining in the lower mantle and characterized by relatively high $\mathrm{Fe}^{3+} / \mathrm{Fe}^{2+}$ ratios, should become relatively oxidized. A dichotomy between upper and lower mantle in terms of $\mathrm{Fe}^{3+} / \mathrm{Fe}^{2+}$ ratio may have resulted, unless complete convective overturn resulted in rehomogenization.

A third possibility is that the spectrum of reduced versus oxidised zones of the upper mantle result from the differential migration of potentially volatile components of the system $\mathrm{C}-\mathrm{H}-\mathrm{O}-\mathrm{S}$. An aureole of reduced peridotite surrounding an ascending, volatile-rich magmatic diapir may result from the relatively rapid escape and diffusion of $\mathrm{H}_{2}$ away from the diapir, and into the surrounding rock (Fig. 10).
It appears that only a combination of further chemical, isotopic and intrinsic $f \mathrm{O}_{2}$ studies on MARID suite nodules, metasomatized peridotite assemblages and various deepseated magma types can be expected to provide firm constraints for models of the evolution of the redox state of the upper mantle.

Acknowledgements. Experimental facilities were made available at the A.N.U. by Professor A.E. Ringwood. For continuing discussion and criticism of the general problems approached in this paper, we are indebted to Dr's Hugh O'Neill and Vic Wall, and to Dr. Matthias Rosenhauer for his constructive review of the draft version of this study. Concurrently and independently, Professor Stephen Haggerty has reached similar conclusions about the heterogeneous redox state of the upper mantle.

\section{References}

Aragón R, McCallister RH (1982) Phase and point defect equilibria in the titanomagnetite solid solution. Phys Chem Minerals $8: 112-120$

Arculus RJ, Delano JW (1981) Intrinsic oxygen fugacity measurements: techniques and results for spinels from upper mantle peridotite and megacryst assemblages. Geochim Cosmochim Acta 45:899-913

Arculus RJ, Gust DA (1981) The intrinsic oxygen fugacity of peridotites from Itinome-gata, Japan, and megacryst ilmenite from the alnöitic breccia of Malaita, Solomon Islands. 1981 IAVCEI Symp Arc Volc Soc Japan and IAVCEI:14-15

Basu AR, Tatsumoto M (1980) Nd isotopes in selected mantlederived rocks and minerals and their implications for mantle evolution. Contrib Mineral Petrol 75:43-54

Boettcher AL, O'Neil JR (1980) Stable isotope, chemical and petrographic studies of high-pressure amphiboles and micas: evidence for metasomatism in the mantle source regions of alkali basalts and kimberlites. Am J Sci 280A:594-621

Carmichael ISE, Nicholls J (1967) Iron-titanium oxides and oxygen fugacities in volcanic rocks. J Geophys Res 72:4665-4687

Dawson JB (1980) Kimberlites and their xenoliths, Springer-Verlag, Berlin, pp 252

Dawson JB, Smith JV (1977) The MARID (mica-amphibole-rutileilmenite-diopside) suite of xenoliths in kimberlite. Geochim Cosmochim Acta 41:309-323

Eggler DH (1983) Upper mantle oxidation state: Evidence from olivine-orthopyroxene-ilmenite assemblages. Geophys Res Lett $10: 365-368$

Elliott WC, Grandstaff DE, Ulmer GC, Buntin T, Gold DP (1982) An intrinsic oxygen fugacity study of platinum-carbon associations in layered intrusions. Econ Geol 77:1493-1510

Frey FA, Prinz M (1978) Ultramafic inclusions from San Carlos, Arizona: petrologic and geochemical data bearing on their petrogenesis. Earth Planet Sci Lett 38:129-176

Frey FA, Green DH, Roy SD (1978) Integrated models of basalt petrogenesis: a study of quartz thöleiites to olivine melilitites from southeastern Australia utilizing geochemical and experimental petrological data. J Petrol 19:463-513

Haggerty SE (1978) The redox state of planetary basalts. Geophys Res Lett 5:443-446

Holmes RD, Arculus RJ (1982) Metal-silicate redox reactions: implications for core-mantle equilibrium and the oxidation state of the upper mantle. Lunar Planet Inst, Planet Volatiles Conf, 45-46

Jaques AL, Gregory GP, Lewis JD, Ferguson J (1982) The ultrapotassic rocks of the west Kimberley region, western Australia, and a new class of diamondiferous kimberlite. Terra Cognita $2: 251-252$

Lawless PJ, Gurney JJ, Dawson JB (1979) Polymict peridotites from the Bulfontein and De Beers Mines, Kimberley, South Africa, in The Mantle Sample: Inclusions in kimberlites and other volcanics. Am Geophys Union: 145-155 
Mao HK (1974) A discussion of the iron oxides at high pressure with implications for the chemical and thermal evolution of the Earth. Carnegie Inst Wash Yearb 73:510-518

Menzies M, Murthy VR (1980) Mantle metasomatism as a precursor to the genesis of alkaline magmas - isotopic evidence. Am J Sci $280 \mathrm{~A}: 622-638$

Mitchell RH (1975) Theoretical aspects of gaseous and isotopic equilibria in the system $\mathrm{C}-\mathrm{H}-\mathrm{O}-\mathrm{S}$ with application to kimberlite. Phys Chem Earth 9:869-881

Mitchell RH (1973) Composition of olivine, silica activity and oxygen fugacity in kimberlite. Lithos 6:65-81

Mo X, Carmichael ISE, Rivers M, Stebbins J (1982) The partial molar volume of $\mathrm{Fe}_{2} \mathrm{O}_{3}$ in multicomponent silicate liquids and the pressure dependence of oxygen fugacity in magmas. Mineral Mag 45:237-245

Nixon PH, Boyd FR (1979) Garnet bearing lherzolite and discrete nodule suites from the Malaite alnoite, Solomon Islands, SW Pacific, and their bearing on oceanic mantle composition and geotherm. in The mantle sample: Inclusions in kimberlites and other volcanics. Am Geophys Union 400-423

O'Neill HStC, Ortez N, Arculus RJ, Wall VJ, Green DH (1982) Oxygen fugacities from the assemblage olivine-orthopyroxenespinel. Terra Cognita 2:228

O'Neill HStC, Navrotsky A (1983) Simple spinels: Crystallographic parameters, cation radii, lattice energies and cation distribution. Am Mineral 68:181-194

Osborn EF (1969) The complementariness of orogenic andesite and alpine peridotite. Geochim Cosmochim Acta 33:307-324

Ringwood AE (1979) Origin of the Earth and Moon. SpringerVerlag, New York, pp 295
Rosenhauer M, Woerman E, Knecht B, Ulmer GC (1977) The stability of graphite and diamond as a function of oxygen fugacity in the mantle. 2nd Intl Kimberlite Conf: Abstr

Ryabchikov ID, Green DH, Wall VJ, Brey GP (1981) The oxidation state of carbon in the reduced-velocity zone. Geokhimiya $2: 221-232$

Sato M (1972) Intrinsic oxygen fugacity of iron-bearing oxide and silicate minerals under low total pressure. Geol Soc Am Mem 135:289-307

Sato M (1978) Oxygen fugacity of basaltic magmas and the role of gas-forming elements. Geophys Res Lett 5:447-449

Sato M (1979) The driving mechanism of lunar pyroclastic eruptions inferred from the oxygen fugacity behaviour of Apollo 17 orange glass. Proc 10th Lunar Planet Sci Conf: 311-325

Sato M, Valenza M (1980) Oxygen fugacities of the layered series of the Skaergaard intrusion, East Greenland. Am J Sci 280A: $134-158$

Ulmer GC, Rosenhauer M, Woermann E (1980) Glimpses of mantle redox conditions. EOS 61:413

Ulmer GC, Rosenhauer M, Woermann E, Ginder T, Drory-Wolff A, Wasilewski P (1976) Applicability of electrochemical oxygen fugacity measurements to geothermometry. Am Mineral $61: 653-660$

Wilshire HG, Shervais JW (1975) Al-augite and Cr-diopside ultramafic xenoliths in basaltic rocks from the western United States. Phys Chem Earth 9:257-272

Received January 17, 1983; Accepted September 5, 1983 